\title{
ENSAIO FOTOGRÁFICO Tornando visíveis os atores sociais que lutam contra o invisível
}

\author{
Marina Garcia Lara ${ }^{1}$ \\ Universidade Federal de Mato Grosso
}

Resumo: Durante o caminhar etnográfico sobre minha pesquisa nos tempos de pandemia, fui tomada por um sentimento descrito anteriormente por Margaret Mead, discípula de Franz Boas e Ruth Benedict. Para além da importância da descrição antropológica dos sujeitos, senti a necessidade de torná-los visíveis. Não obstante, vivemos em um momento que sugere distanciamento social entre pesquisador e entrevistados, e o sentimento de contato é aflorado com o passar dos dias. Assim sendo, em uma tarde ensolarada de uma quinta-feira do mês de setembro, inevitavelmente comecei a observar a vida que acontecia fora de mim. Ainda que não possa ver os atores específicos da pesquisa, sair pelas ruas do centro da cidade de Cuiabá me fez compreender, através de imagens, que há um mundo de atores sociais a serem seguidos: eis aqui o resultado fotográfico do meu encontro com os cuidados, conhecimento, fé e esperança.

Palavras-chave: Covid-19; Cuiabá; máscara; cidade. 


\title{
Making visible the social actors who fight against the invisible
}

\begin{abstract}
During the ethnographic walk about my research in pandemic times, I was taken by a feeling previously described by Margaret Mead, a disciple of Franz Boas and Ruth Benedict. In addition to the importance of the subjects' anthropological description, I felt the necessity to make them visible. Nevertheless, we live in a moment that suggests social distance between the researcher and the interviewees, and the feeling of contact increases over the days. So, on a sunny Thursday afternoon in September, I inevitably began to observe life outside me. Although I cannot see the specific actors of the research, going out through the streets of downtown Cuiabá made me understand, through images, that there is a world of social actors to be followed: here it is the photographic result of my encounter with care, knowledge, faith and hope.
\end{abstract}

Keywords: Covid-19; Cuiabá; mask; city.

\section{Visibilizar los actores sociales que luchan contra lo invisible.}

\begin{abstract}
Resumen: Durante el paseo etnográfico sobre mi investigación en tiempos de pandemia, me embargó un sentimiento previamente descrito por Margaret Mead, discípula de Franz Boas y Ruth Benedict. Además de la importancia de la descripción antropológica de los sujetos, sentí la necesidad de hacerlos visibles. Sin embargo, vivimos un momento que sugiere un distanciamiento social entre el investigador y los entrevistados, y la sensación de contacto surge con el paso de los días. Entonces, en una soleada tarde de jueves de septiembre, comencé inevitablemente a observar la vida fuera de mí. Aunque no puedo ver los actores específicos de la investigación, salir por las calles del centro de Cuiabá me hizo comprender, a través de imágenes, que hay un mundo de actores sociales a seguir: aquí está el resultado fotográfico de mi encuentro con el cuidado, el conocimiento, la fe y la esperanza.
\end{abstract}

Palabras clave: Covid-19; Cuiabá; máscara; ciudad. 


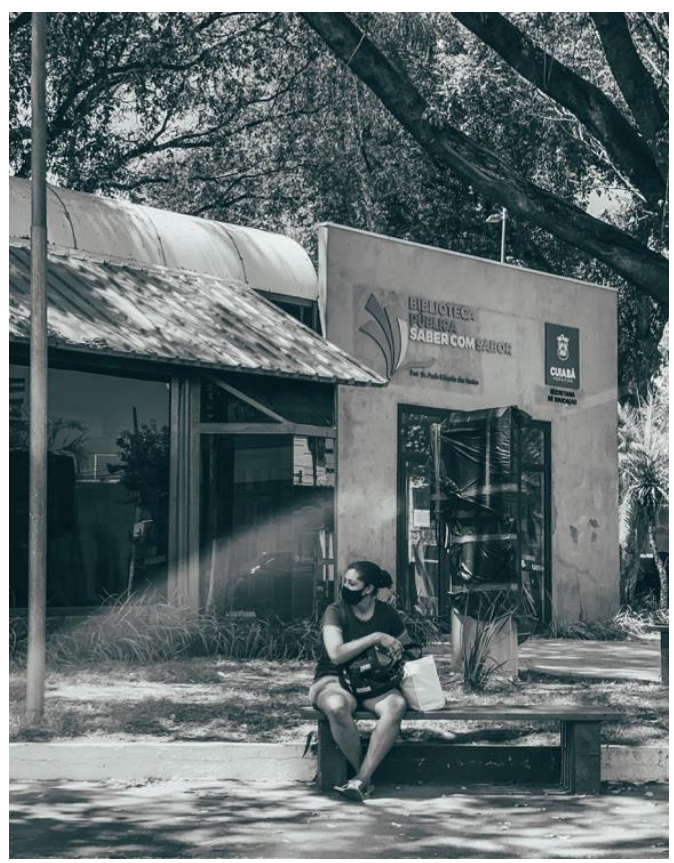

Foto 1 - Conhecimento, o plano de fundo de uma espera pelo fim.

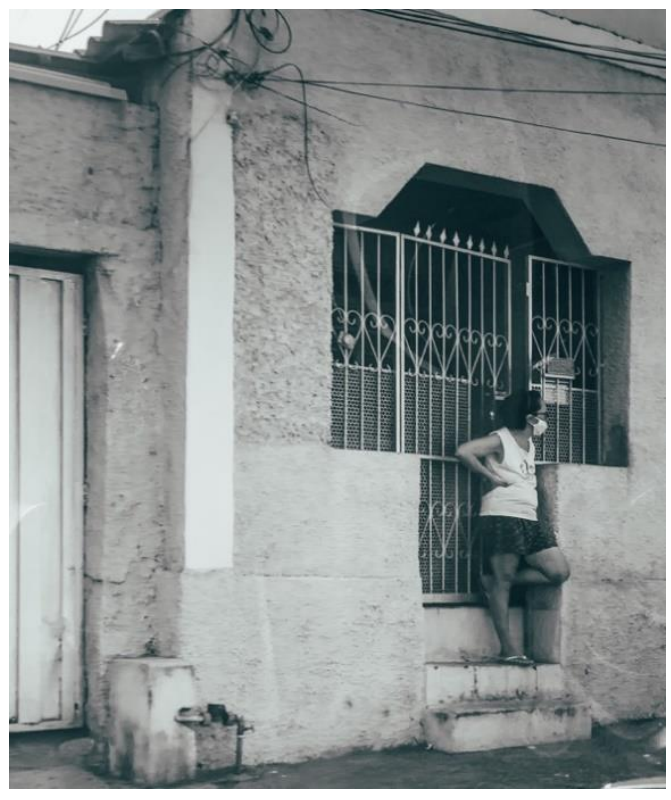

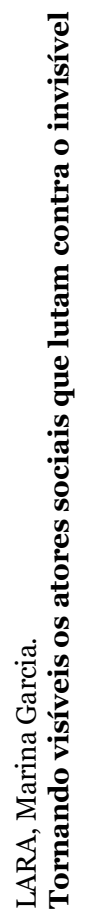

Foto 2 - Anseio pelo retorno - ou pela espera? 


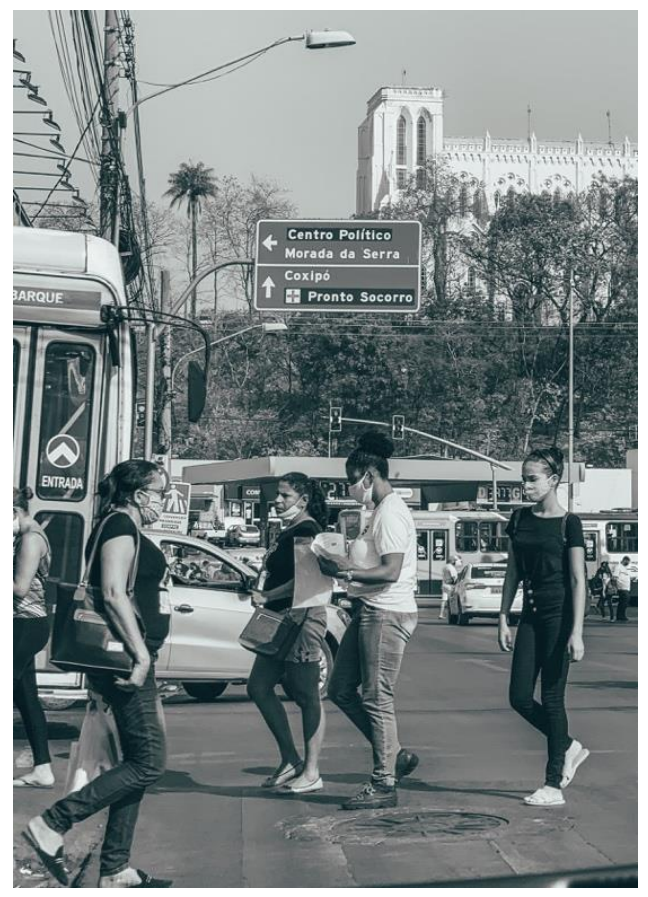

Foto 3 - A vida que acontece sob a Sombra (Sol) da fé

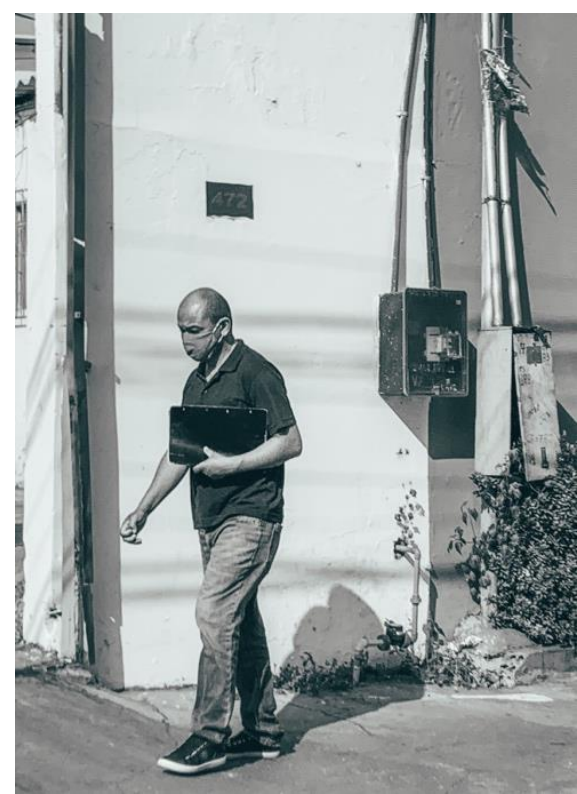

Foto 4 - Um mundo sem pressa. 


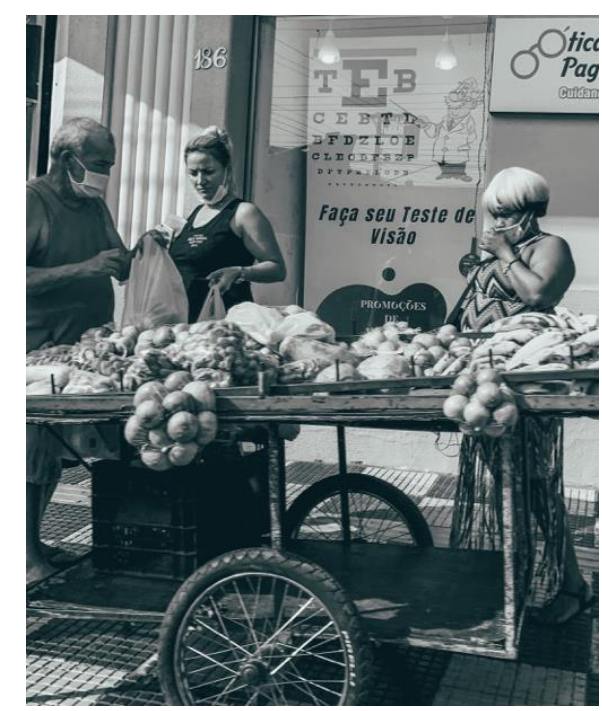

Foto 5 - O sabor do momento.

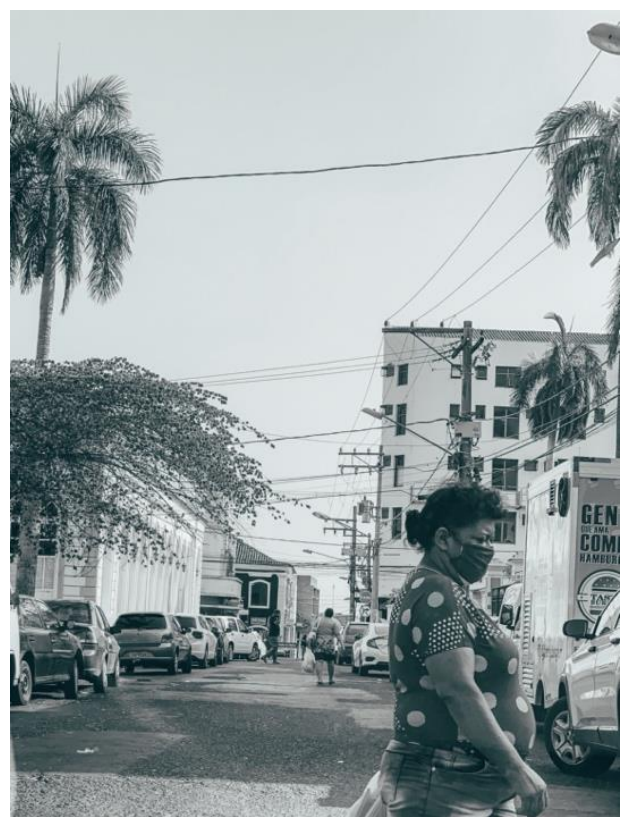

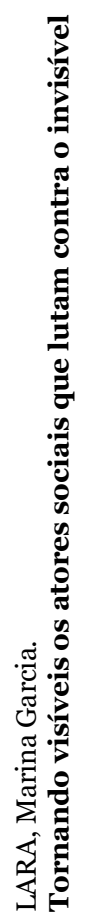

Foto 6 - Dia de feira, quinta-feira. 


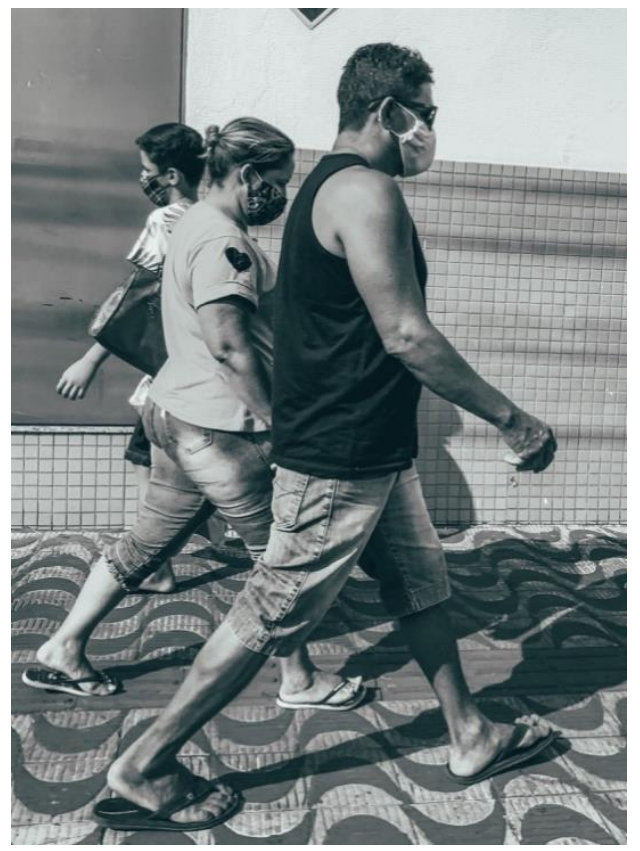

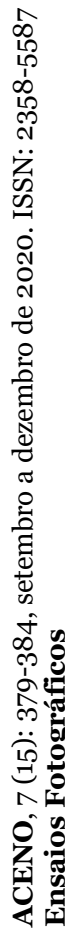

Foto 7 - Certeza da vida, ela continua.

Recebido em 15 de setembro de 2020.

Aceito em 12 de dezembro de 2020. 